\title{
The Problem (and the Answer?) to the Limited Availability of Pain Psychologists: Can Clinical Social Workers Help?
}

This article was published in the following Dove Press journal:

Journal of Pain Research

\author{
Michael E Schatman (iD) 1,2 \\ Matthew G Fortino 1,3,4 \\ 'Department of Diagnostic Sciences, \\ Tufts University School of Dental \\ Medicine, Boston, MA, USA; \\ ${ }^{2}$ Department of Public Health and \\ Community Medicine, Tufts University \\ School of Medicine, Boston, MA, USA; \\ ${ }^{3}$ Department of Clinical Psychology, \\ William James College, Newton, MA, \\ USA; ${ }^{4}$ Department of Anesthesia, Critical \\ Care and Pain Medicine, Massachusetts \\ General Hospital, Boston, MA, USA
}

Correspondence: Michael E Schatman Tel + I425647-4880

Email Michael.Schatman@tufts.edu

\section{Introduction}

American chronic pain medicine has been in a state of crisis for many years, with the overall quality of care continuing to deteriorate. In a 3-part series published in 2008, Giordano and Schatman discussed this crisis, ${ }^{1-3}$ elucidating the notion that chronic pain care would not reach its potential if we failed to emphasize multidisciplinary care focused on the needs of patients. More than a decade later, it is quite apparent that our warnings were not heeded. Much of this failure has been related to the devolution of the "profession" of pain medicine to the "business" of pain medicine, ${ }^{4}$ which has been due to numerous factors. These have included, but not necessarily been limited to, the malevolent dominance of the health insurance industry, ${ }^{5,6}$ progressive corporatization, ${ }^{7}$ fraudulent marketing, ${ }^{8}$ industry's detrimental influence on medical education, ${ }^{9,10}$ a lack of undergraduate medical education in pain management, ${ }^{11}$ and, of course, the profound swing of the "opioid pendulum" from reckless opiophilia to its current zeitgeist of often cruel opiophobia, ${ }^{12-14}$ and last but not least, the demise of interdisciplinary pain care. $^{15-18}$

Interdisciplinary pain care is based on the biopsychosocial model of pain management, rejecting a purely biomedical model. Rather, the approach accounts for the interconnectivity between biology, psychology, and socio-environmental factors. Although this approach was first elucidated by Engel in 1977, ${ }^{19}$ the biopsychosocial approach had actually been applied in the earliest interdisciplinary chronic pain management programs, dating back to William Livingston's training of the psychologist, Ronald Melzack, at the experimental pain management program at the University of Oregon in $1947 .{ }^{20}$ Another early pioneer in interdisciplinary care, John Bonica, partnered with the psychologist, Wilbert Fordyce, who introduced operant conditioning to pain management at the University of Washington. ${ }^{21}$ Interdisciplinary programs began to proliferate, and always included psychologists, who were seen as instrumental members of the treatment team. Cognitive behavioral therapy (CBT) has long been considered the mainstay of psychological intervention in interdisciplinary chronic pain management programs, ${ }^{22}$ with $\mathrm{CBT}$ techniques including cognitive restructuring, respondent and operant conditioning, acceptance and commitment therapy, hypnosis, biofeedback, meditation, guided imagery and other relaxation training techniques, motivational interviewing, and psychoeducation 
("corrective feedback"). ${ }^{23}$ Additionally, psychologists in interdisciplinary pain management are responsible for providing comprehensive psychosocial evaluations, facilitate effective communication between members of the treatment team, and evaluate and monitor treatment outcomes. ${ }^{24}$

Despite their considerable value in treating chronic pain biopsychosocially, the United States is currently faced with a dramatic shortage of trained pain psychologists. Darnall et al noted that despite the enactment of the Mental Health Parity Act as an aspect of the Affordable Care Act resulting in greater ease of access to mental health care, the limited number of psychologists trained and experienced in chronic pain has resulted in few good options for patients needing attention to the psychosocial aspects of their chronic pain. ${ }^{25}$ Results of a 2016 study indicated that the majority of mental health providers did not feel comfortable in treating patients with chronic pain, ${ }^{26}$ and even if a therapist expresses "comfort" in treating this population, this does not necessarily translate to competence. Perhaps exacerbating the current shortage is the tendency for many postdoctoral fellowships in pain psychology to emphasize the training of pain researchers, resulting in many pain psychologists working as researchers rather than clinicians. Although Darnall et al ${ }^{25}$ wrote of the "ethical imperative" and "social responsibility" associated with the training and availability of more pain psychologists to provide clinical care, there is no evidence that their call to arms has resulted in any changes.

\section{A Solution?}

The lack of access to pain psychologists is not going to improve anytime in the foreseeable future. However, patients suffering from chronic pain have the right, ethically, to biopsychosocial treatment, as failure to provide such care is responsible for individual and systemic suffering. Recently, more clinical social workers have been hired and trained in chronic pain management, although this is hardly a new concept. As early as 1977, when Hudgens, a social worker, described her behavioral treatment of chronic pain patients. ${ }^{27}$ The author astutely noted that the humanistic tradition of social work emphasizes the need to consider each chronic pain patient a unique individual, which is especially salient at a time when the government is strongly urging that pain providers operate under models of individualized care. ${ }^{28}$ The article describes an operant approach, and includes the family in treatment - something that pain psychologists too frequently fail to do. Although Hudgens may have been the first to describe psychosocial management of chronic pain by social workers in the literature, others followed. ${ }^{29-33}$

More compelling than the literature, perhaps, is that we have witnessed social workers becoming excellent chronic pain clinicians. The first author of this analysis (MES) has trained 2 experienced social workers to become extremely capable behavioral pain care clinicians in interdisciplinary settings. Apparently, his experience has not been unique. For example, at the Pain Psychology Center in Beverly Hills, CA, of their 25 pain therapists, 11 are social workers, and, interestingly, only one is a psychologist. ${ }^{34}$ In speaking to the Center's Executive Director, we were pleased to learn that he is in the process of developing a specialized training program for MSWs at the facility (Alan Gordon, LCSW, telephone communication, December 4, 2020). It is also important to consider the number of social workers (MSWs) vs clinical psychologists graduating each year in the United States. The most recent data from 2018 indicated that 27,659 MSWs graduated the previous year, ${ }^{35}$ with only 6403 doctoral level psychologists graduating in 2019, with only 3365 of these doctorates awarded from programs training psychologists to be health care providers. ${ }^{36}$ In consideration of the supply of viable providers, the number of clinically trained social workers eclipses the number of psychiatrists, psychologists, and psychiatric nurses combined. ${ }^{37}$ Issues of cost-effectiveness also should be considered, as an MSW is generally a 2-year degree, while a doctorate in psychology requires $4+$ years, a year of internship, and the completion of a post-doctoral fellowship in pain or health psychology.

All of these factors support the imperative of producing more social workers who are trained in pain management. We opine that with the exception of certain psychometric testing, there is little, if anything, that a well-trained social worker cannot do that can be done by a pain psychologist. Social workers are well positioned to effectively deliver pain medicine as best practice, a sentiment declared by the National Association of Social Workers, the largest professional social work organization in the United States. ${ }^{38}$ In Massachusetts, the need for better solutions to chronic pain management was recognized by a joint effort of the governor's office along with the state's nine schools of social work. ${ }^{39}$ Accordingly, it would be false to claim that social work institutions are totally absent on the front of chronic pain management. There exist social work programs in every state that feature continuing education (CE) courses in pain management. Top graduate schools of 
social work already demonstrate research initiatives to recruit students, treat pain, and manifest efforts that integrate interprofessional practice. ${ }^{40,41}$ Although select MSW programs offer post graduate certifications that detail aspects of pain management, these offerings remain independent of the core curricula. A review of social work programs in the US reveals that pain management competencies, if addressed at all in social work curricula, are often tucked within palliative care concentrations or are presented to students as part of the prevention and management of substance use disorders. ${ }^{42,43}$ Notwithstanding the value in controlled substance risk mitigation, even within these topics, pain management is largely addressed on the periphery of substance misuse education. ${ }^{11}$ A more targeted approach is needed to teach incoming students the skills they need to adapt to the shifting trends in the labor market.

\section{The Solution}

Hiring faculty with a background in pain management can provide students with the opportunity to learn from professors with clinical experience and knowledge of trajectories where they can actualize their skills upon graduation. In a similar vein, involving teaching staff with expertise in interprofessional education can acclimate social workers to the infrastructure of integrated care, as studies suggest that the comprehension of cotreating providers functions is indicative of high health care team performance. This in turn can lead to a quicker deployment of new social workers entering the workforce so that they can be better positioned to "contribute to the decisions that affect the well-being of clients by drawing on the perspectives, values, and experiences of the social work profession". ${ }^{44}$ In addition to the development of didactic opportunities MSW students need hands-on clinical training if they are going to become competent behavioral pain management professionals. As graduate programs in social work tend to place a heavy emphasis on practica in clinical settings, access to opportunities to work with patients and see patients in pain management departments and facilities is imperative. Although the aforementioned efforts of the Center for Pain Psychology to formally train more MSWs and MSW students represents an important endeavor, interested social workers will ideally have the opportunity to begin pain training while working toward their MSWs. We recently reached out to a number of Boston-area MSW programs' directors in order to discuss the possibility of setting up didactive electives as well as externship placements in pain management, and were disappointed by the lack of interest. Accordingly, the authors intend to disseminate this article to the program directors of all MSW programs in the country in order to help them understand that this represents an opportunity for social work to step up to the plate and help fix what is currently a very broken system. We appreciate that the paradigmatic revision that we have proposed is a seemingly radical one. However, given that the very vast majority of the 50 million chronic pain patients in the US are currently receiving woefully inadequate treatment, we opine that working together to train thousands of social workers to be leaders in behavioral treatment of chronic pain will be imperative if our pain management system is to be reconstructed in a manner that will give patients opportunities to reclaim the quality of their lives.

\section{Disclosure}

Dr Michael E Schatman is a research consultant for Firstox and Modoscript. The authors report no other conflicts of interest in this work.

\section{References}

1. Giordano J, Schatman ME. An ethical analysis of crisis in chronic pain care. Part 1. Facts, issues, and problems in pain medicine. Pain Physician. 2008;11:483-490.

2. Giordano J, Schatman ME. A crisis in chronic pain care: an ethical analysis; Part 2. Proposed structure and function of an ethics of pain medicine. Pain Physician. 2008;11:589-595.

3. Giordano J, Schatman ME. A crisis in chronic pain care: an ethical analysis. Part 3: toward an integrative, multi-disciplinary pain medicine built around the needs of the patient. Pain Physician. 2008;11:771-784.

4. Schatman ME, Lebovits AH. On the transformation of the "profession" of pain medicine to the "business" of pain medicine: an introduction to a special series. Pain Med. 2011;12:403-405. doi:10.1111/ j.1526-4637.2011.01059.x

5. Schatman ME. The role of the health insurance industry in perpetuating suboptimal pain management: ethical implications. Pain Med. 2011;12:415-426. doi:10.1111/j.1526-4637.2011.01061.x

6. Schatman ME, Webster LR. The health insurance industry: perpetuating the opioid crisis through policies of cost-containment and profitability. J Pain Res. 2015;8:153-158. doi:10.2147/JPR.S83368

7. Meghani SH. Corporatization of pain medicine: implications for widening pain care disparities. Pain Med. 2011;12(4):634-644. doi:10.1111/j.1526-4637.2011.01074.x

8. Taylor ML. The impact of the "business" of pain medicine on patient care. Pain Med. 2011;12(5):763-772. doi:10.1111/j.15264637.2011.01114.x

9. Perret D, Rosen C. A physician-driven solution-the Association for Medical Ethics, the Physician Payment Sunshine Act, and ethical challenges in pain medicine. Pain Med. 2011;12(9):1361-1375. doi:10.1111/j.1526-4637.2011.01217.x 
10. Schofferman J. The medical-industrial complex, professional medical associations, and continuing medical education. Pain Med. 2011;12 (12):1713-1719. doi:10.1111/j.1526-4637.2011.01282.x

11. Loeser JD, Schatman ME. Chronic pain management in medical education: a disastrous omission. Postgrad Med. 2017;129:332-335. doi:10.1080/00325481.2017.1297668

12. Schatman ME, Darnall BD. A pendulum swings awry: seeking the middle ground on opioid prescribing for chronic non-cancer pain. Pain Med. 2013;14:617-620. doi:10.1111/pme.12120

13. Atkinson TJ, Schatman ME, Fudin J. The damage done by the war on opioids: the pendulum has swung too far. J Pain Res. 2014;7:265268. doi:10.2147/JPR.S65581

14. Schatman ME, Vasciannie A, Kulich RJ. Opioid moderatism and the imperative of rapprochement in pain medicine. $J$ Pain Res. 2019;12:849-857. doi:10.2147/JPR.S198849

15. Schatman ME. The demise of the multidisciplinary chronic pain management clinic: bioethical perspectives on providing optimal treatment when ethical principles collide. In: Schatman ME, editor. Ethical Issues in Chronic Pain Management. New York: Informa Healthcare; 2007:43-62.

16. Schatman ME. Interdisciplinary chronic pain management: perspectives on history, current status, and future viability. In: Ballantyne JC, Rathmell JP, Fishman SM, editors. Bonica's Management of Pain. 4th ed. Philadelphia: Lippincott, Williams \& Wilkins; 2010:1523-1532.

17. Schatman ME. Interdisciplinary chronic pain management: international perspectives. Pain Clin Updates. 2012;20(7):1-5.

18. Schatman ME. The demise of interdisciplinary chronic pain management and its relationship to the scourge of prescription opioid diversion and abuse. In: Peppin J, Coleman J, Dineen KK, Ruggles A, editors. Pain and Prescription Drug Diversion: Healthcare, Law Enforcement, and Policy Perspectives. New York: Oxford University Press; 2018:204-218.

19. Engel GL. The need for a new medical model: a challenge for biomedicine. Science. 1977;196(4286):129-136. doi:10.1126/ science. 847460

20. Livingston WK. Pain and Suffering. Seattle, WA: International Association for the Study of Pain Press; 1998.

21. Fordyce WE. Behavioral Methods in Chronic Pain and Illness. St. Louis, MO: CV Mosby; 1976.

22. Eccleston C. Role of psychology in pain management. Br J Anaesth. 2001;87(1):144-152. doi:10.1093/bja/87.1.144

23. Turk DC, Swanson KS, Tunks ER. Psychological approaches in the treatment of chronic pain patients-when pills, scalpels, and needles are not enough. Can J Psychiatry. 2008;53(4):213-223. doi:10.1177/ 070674370805300402

24. Gatchel RJ, McGeary DD, McGeary CA, Lippe B. Interdisciplinary chronic pain management: past, present, and future. Am Psychol. 2014;69(2):119-130. doi:10.1037/a0035514

25. Darnall BD, Carr DB, Schatman ME. Pain psychology and the biopsychosocial model of pain treatment: ethical imperatives and social responsibility. Pain Med. 2017;18:1413-1415. doi:10.1093/ $\mathrm{pm} / \mathrm{pnw} 166$

26. Darnall BD, Scheman J, Davin S, et al. Pain psychology: A global needs assessment and national call to action. Pain Med. 2016;17 (2):250-263. doi: $10.1093 / \mathrm{pm} / \mathrm{pnv} 095$

27. Hudgens AJ. The social worker's role in a behavioral management approach to chronic pain. Soc Work Health Care. 1977;3(2):149-157. doi:10.1300/J010v03n02_03

28. United States Department of Health and Human Services. Pain Management Best Practices Inter-Agency Task Force Report: updates, gaps, inconsistencies, and recommendations; May 9, 2019. Available from: https://www.hhs.gov/sites/default/files/pmtf-finalreport-2019-05-23.pdf. Accessed December 4, 2020.
29. Smith LL. Helping to manage the emotional effects of arthritis. Health Soc Work. 1979;4(3):134-150. doi:10.1093/hsw/4.3.135

30. Roy R. Social work and chronic pain. Health Soc Work. 1981;6 (3):54-62. doi:10.1093/hsw/6.3.54

31. Subramanian K, Rose SD. Social work and the treatment of chronic pain. Health Soc Work. 1988;13(1):49-60. doi:10.1093/hsw/13.1.49

32. Pavlek M. Paining out: an integrative pain therapy model. Clin Soc Work J. 2008;36:385-393. doi:10.1007/s10615-007-0136-y

33. Pasquale M, Seehaus M, Horton R. The role of social work in an interdisciplinary pain clinic team treating rheumatologic/musculoskeletal conditions. J Pain. 2011;12(4Suppl):28. doi:10.1016/j. jpain.2011.02.115

34. Pain Psychology Center. Our team. Available from: https:/www. painpsychologycenter.com/our-team.html. Accessed December 3, 2020.

35. The Council on Social Work Education; National Workforce Initiative Steering Committee. Results of the Nationwide Survey of 2017 Social Work Graduates; 2018. Available from: https://www. cswe.org/Centers-Initiatives/Initiatives/National-WorkforceInitiative/Survey-of-2017-SW-Grads-Report-FINAL.aspx. Accessed December 24, 2020.

36. American Psychological Association. Doctorate Degrees in Psychology, 2004-2019. Available from: https://www.apa.org/work force/data-tools/degrees-psychology. Accessed December 4, 2020.

37. Beck A, Page C, Buche RD, Gaiser M Mapping supply of US psychiatric workforce; October 2018. Available from: https://beha vioralhealthworkforce.org/wp-content/uploads/2019/01/Y3-FA1-P2Psych-Mapping-Full-Report-with-Appendix.pdf. Accessed December 9, 2020.

38. National Association of Social Workers. Re: HHS-OS-2018-0027pain management best practices inter-agency task force draft report on pain management best practices; March 26, 2019. Available from: https://www.socialworkers.org/LinkClick.aspx?fileticket=F1A1t2Boio\%3D\&portalid=0. Accessed December 5, 2020.

39. Social Work Education Core Principles for the Prevention and Management of Substance Misuse. Governor's Social Work Education Working Group on Substance Misuse; October 2017. Available from: https://www.mass.gov/files/documents/2017/10/06/ Social\%20Work\%20Core\%20Principles\%20Draft\%2010-4-17.pdf. Accessed December 5, 2020.

40. Association of American Medical Colleges. How academic medicine is addressing the opioid crises; February 2019. Available from: https://www.aamc.org/system/files/d/1/63-opioids_-_how_academic_ medicine_is_addressing_the_opioid_epidemic_-_20190222.pdf. Accessed December 5, 2020.

41. University of Washington. Scan design foundation innovations in pain research summer program. Available from: https://www.washing ton.edu/undergradresearch/pain-research/. Accessed December 5, 2020.

42. Smith School for Social Work. Palliative/ELC certificate curriculum. Available from: https://ssw.smith.edu/academics/continuing-educa tion/graduate-certificate-programs/certificate-palliative-and-end-life1. Accessed December 5, 2020.

43. Leaders in research against the opioid epidemic. OSU.edu. Available from: http://csw.osu.edu/wp-content/uploads/2017/04/2017-4-April_ CSW-Leaders-in-Research-against-Opioids.pdf. Accessed December 5, 2020.

44. National Association of Social Workers. Code of ethics, section 2.0. Available from: https://www.socialworkers.org/About/Ethics/Codeof-Ethics/Code-of-Ethics-English1996. Accessed December 10, 2020 . 


\section{Publish your work in this journal}

The Journal of Pain Research is an international, peer reviewed, open access, online journal that welcomes laboratory and clinical findings in the fields of pain research and the prevention and management of pain. Original research, reviews, symposium reports, hypothesis formation and commentaries are all considered for publication. The manuscript management system is completely online and includes a very quick and fair peer-review system, which is all easy to use. Visit http:// www.dovepress.com/testimonials.php to read real quotes from published authors. 